\title{
The Pensions Ombudsman - A review
}

Received: (in revised form): 14th September, 2004

\section{Chris Busby}

leads Eversheds' Pensions Litigation team in the Midlands. He is a solicitor advocate with broad experience of dealıng with contractual disputes both in court and by way of negotıatıon, mediation and expert determınation. Since 1998, he has specialised in pensions litigation, dealing with all aspects of contentious pensions work including court proceedings and investigations by the Pensions Ombudsman (ıncluding acting as advocate before the Ombudsman).

Abstract This paper provides a review of the office of the Pensions Ombudsman, with advice to those coming into contact with the office, and suggests how things may change in the future.

Keywords: pensions; Ombudsman; delay; legal costs; jurisdiction; appeal

\section{Introduction}

David Laverick, the Pensions

Ombudsman, is approaching a crossroads. His office is coming under scrutiny both for delay and for decisions which depart from the practice of his predecessor, $\mathrm{Dr}$ Julian Farrand. At the same time, the Department for Work and Pensions (DWP) has been considering over the past 12 months whether to make changes to the office. This paper examines the present position and provides advice to those coming into contact with the office. It also looks at how things may change in the future.

\section{History}

The office of the Pensions Ombudsman opened in April 1991. The office has about 30 staff at present and is funded by

Chris Busby

Eversheds LLP,

115 Colmore Row,

Bırmingham, B3 3AL, UK

$\mathrm{Tel}+44(0) 1212321000$,

Fax. $+44(0) 1212321915$,

e-mall

chrisbusby@eversheds.com the DWP and, indirectly, from the levy on pension schemes.

At the time the office was established, there was a debate within the pensions industry as to whether it would be more appropriate to have a tribunal rather than an Ombudsman, akin to the current employment tribunal system. The latter was favoured by the industry, particularly the Occupational Pensions Board. ${ }^{1}$ In the event, Parliament decided on an Ombudsman.

Since 1991 there have been three Ombudsmen - Michael Platt (1991-1994), Dr Julian Farrand (1994-2001) and, since September 2001, David Laverick. The scope of the Ombudsman's jurisdiction is complicated. A great deal of time is spent by lawyers and the Ombudsman's office dealing with queries as to whether or not the Ombudsman has jurisdiction to deal with the particular matters. It all depends on who is bringing the complaint and the nature of the matter.

\section{Recovery of professional fees}

The essence of the Pensions Ombudsman service is that it provides an accessible, timely and cost-effective way of resolving pensions complaints or disputes. Probably the most critical element of this is that 
members of pensions schemes are able to make a complaint without having to incur professional fees or getting involved in formal and daunting court processes. In the early years after the Ombudsman's office opened, it was established practice that, if etther a complainant or a respondent chose to instruct lawyers, they would not recover the legal costs, whatever the outcome of the complaint.

This changed in July 2001, when legal costs were awarded against a respondent by Dr Julian Farrand. ${ }^{2}$ In that case, the Ombudsman considered the case to have exceptional circumstances which led him to this decision.

This issue next arose in February 2003, when the present Ombudsman also awarded costs against a respondent. ${ }^{1.3}$ This has turned out to be the first in a series of decisions where the

Ombudsman has awarded costs to a successful complainant.

The Ombudsman draws his authority to award costs from his general power to direct trustees, managers, employers or administrators to "take, or refrain from taking, such steps as he may specify'. There is little doubt that it is within the Ombudsman's powers at present to award costs in this way but it is a worrying trend that this power is being increasingly used especially as there is no clear guidance to determine precisely how a complaint qualifies for legal costs to be awarded.

Employers, trustees and administrators are faced with many bogus claims from complainants which can involve them in great expense in legal costs. Despite this, the Ombudsman has no power at present to require a complainant to pay the respondent's legal costs for an unsuccessful complaint, whatever the circumstances. This contrasts with the court's system where the ability to recover legal costs, whatever the type of claim, is the same for both parties.
The respondents to a complaint have no choice but to respond fully to any allegations and to deal with questions from the Ombudsman over what may be many months. Where a complainant does choose to instruct lawyers, a respondent now needs to consider very carefully how it responds. It may be that trying to resolve a complaint amicably will be more cost-effective (assuming a settlement could be justified on legal grounds), given the risk of paying what may be substantial legal costs.

The possible risks for respondents were brought into focus in a case in 2003 where a widow was awarded $£ 100$ for distress and inconvenience, plus legal costs of $£ 1,054 .{ }^{5}$ The case concerned the award to a widow of a widow's pension in circumstances where the Ombudsman admitted that a court could not have given this remedy. Had court proceedings been brought in the same matter, not only would the main complaint have falled, but the widow would almost certainly not have recovered any legal costs. The disparity between the Ombudsman's approach and the court's was something that was considered by the DWP in the pre-Pensions Bill consultation although no changes on this issue appear in the Pensions Act 2004. This may change in the future but in the meantime, respondents should be aware of the risk of having legal costs awarded against them.

\section{Delay}

The Ombudsman's stated target for handling a complaint is that the average time of all investigations from application to final decision will not be more than 12 months.

The Ombudsman's annual report (for the year ending 31st March, 2003) painted a picture of an office that is under-resourced and struggling to cope 
with the number of new complaints and disputes that it is receiving.

The report showed a marked increase in the number of cases taking more than 12 months to be resolved. The Ombudsman's latest annual report (for the year ending 31st March, 2004) was published in July 2004. In this report the Ombudsman explained that, although he strll does not have all the resources he needs, positive steps have been taken to reduce the backlog of investigations. An additional team of investigative staff has been set up to concentrate on clearing those cases which have been in the system the longest. The Ombudsman reported that, as a result of these changes, there has been an increase in the number of investigations closed and work has been completed on some long-standing complaints. Furthermore, new complaints are being dealt with far more quickly.

Despite these positive steps, however, the Ombudsman reported that he has still not managed to keep pace with the number of cases accepted for investigation and there remains some investigations that are taking far too long. This comes at a time when the profile of pensions could not be higher and it is not surprising that, in the last financial year, new casework reached an all time high of 1394 cases being accepted as within the Ombudsman's jurisdiction.

So what is the solution? For a complainant, the reality is that a court may sometimes be quicker, even if it is a more formal process. The complainant needs to bear in mind, however, that they could receive an adverse costs order if they lose in court, which is not presently a risk for a case before the Ombudsman.

For a respondent, it is possible to issue proceedings seeking a declaration in relation to the issue in question from the court prior to the matter being referred to the Ombudsman. This will potentially avoid a loss of choice over the forum for the dispute to be determined as the Ombudsman cannot have jurisdiction to deal with a matter that is already the subject of court proceedings. In most cases, however, it is likely that a respondent will have no choice but to submit to the jurisdiction of the Ombudsman and respond to the complaint over whatever period it takes. If there is a delay, there is the option to complain to the Parliamentary Ombudsman, but this in itself takes time and will only be worth considering in extreme cases. If lawyers are instructed, legal costs are likely to be higher if the complaint runs for longer and respondents should plan for this in allocating any resources to the problem. The reality is that there are unlikely to be any short-term answers as the Ombudsman continues to grapple with increased numbers of complainants and the limited resources available to him.

\section{The future}

The DWP considered making changes to the operation of the Ombudsman's office. Very little change actually appears in the Pensions Act 2004. Some of the areas considered were as follows.

\section{Appointing a Deputy Ombudsman}

As things currently stand, the Pensions Ombudsman must sign off all decisions as his own. If the Ombudsman were ill, an immediate problem arises. Section 274 of the Pensions Act 2004 provides for the appointment of a deputy to the Ombudsman. This person will be permitted to perform the functions of the Ombudsman at any time when the Ombudsman is for any reason unable to discharge his functions, or at any time with the consent of the Secretary of 
State. In practice, this overcomes the situation where the Ombudsman is ill or unavailable. It also enables a deputy Ombudsman to be appointed at times of high demand, perhaps to deal with a group of like cases or to handle time-consuming oral hearings.

While this is sensible, it does raise the issue as to whether two different decision makers would lead to inconsistent decisions.

\section{Jurisdiction}

The Ombudsman's jurisdiction remains largely unchanged by the Pensions Act 2004 despite the consultation prior to the Act looking at various options for simplifying what is currently a complicated situation. The Ombudsman's jurisdiction has widened over the years through various regulations. The DWP considered removing the various layers about who can complain and refer disputes and about whom. The proposal was that the Ombudsman should be able to investigate and determine any complaint of maladministration made by a person in connection with an occupational or personal pension scheme provided injustice has been suffered as a result of the maladministration. The DWP's stated intention in making this proposal was to simplify matters rather than to widen the Ombudsman's jurisdiction.

In reality, however, the above definition would have considerably widened the jurisdiction. The jurisdiction suggested above would allow such a complaint to be brought which might otherwise have been dealt with by the courts. It is difficult to see how the jurisdiction can be simplified without widening the jursdiction at a time when resources are tight to meet the existing case load. It is, therefore, not surprising that the Pensions Act introduces very little change.

The one change that has been made is to clarify the definition of what is an 'administrator' for the purposes of the existing rules. This follows the Court of Appeal's decision in Britannic ${ }^{6}$ where the court held that the test is not whether a pension carries out administrative activities but whether the pension is concerned with the administration of the scheme. Section 275 Pensions Act 2004 clarifies the existing definition of 'administrator" ${ }^{7}$ to be a pension or body responsible for carrying out an act of administration concerned with the scheme. This in effect widens the definition set by the Court of Appeal in Britannic. Notwithstanding this, it is likely that there will continue to be debate in the future as to whether a particular respondent falls within the definition of an 'administrator' as it will depend on the facts of each case.

\section{Maladministration}

There has been an on-going tension between the courts and the Ombudsman as to the extent of the Ombudsman's discretion to investigate and determine issues relating to maladministration. It has been suggested by the courts that the Ombudsman should not be entitled to make an order of a kind which a Court could not make. ${ }^{8}$ In his most recent report, the Ombudsman observed that there is no statutory statement to this effect. His interpretation was that Ombudsmen were intended to provide remedies in circumstances and where appropriate of a kind which differ from those available from the courts.

The Ombudsman process is meant to be inquisitorial and therefore different from the alternative Court process. The Ombudsman has expressed the view that his decisions can have a wider ambit 
than the legal principles that constrain the court. The DWP consulted on the possibility of changing the Ombudsman's jurisdiction such that his decisions would be made on the basis of what is 'fair and reasonable'. This doesn't appear in the Pensions Act 2004 but may well re-appear as a proposal in due course. A difficulty remains when one tries to make such an approach fit with the current appeal process which is based on a point of law.

\section{Recovery of costs}

There is a proposal by the DWP to allow the Pensions Ombudsman to require a vexatious complainant to pay the costs of a respondent having to deal with the complaint. This perhaps is a little narrow. Rules akin to those in the small claims track of the court system may well be appropriate here. This allows the court to require a claimant who is acting unreasonably to pay the costs of the defendant in circumstances where costs would not otherwise be payable.

\section{Appeal}

Currently, a losing party can appeal the decision of the Ombudsman to the High Court on a point of law. The DWP was proposing to require an appellant to get permission from the High Court before the appeal can be pursued. This would mean that there would be a screening process to make sure that unmeritorious appeals did not progress. This seems sensible and follows the general approach of the courts since the Civil Procedure
Rules were introduced. That said, there is a school of thought that something akin to the Employment Appeals Tribunal would be a more appropriate appeal route than the courts, as industry experts could sit on a panel of judges and might be better equipped to deal with the concept of maladministration. The Pensions Act 2004 has not included any provision on this issue but it may still be clarified in the future.

It does seem likely that the changes that were being considered would only serve to widen the Ombudsman's role. The resources available to the Ombudsman will have to be addressed again if this is to take place as the current situation is unsustainable. Even as things stand, complainants are still faced with possible delays when making a complaint. If a party has a choice as to whether or not to use the services of the Ombudsman, consideration as to the implications of your decision should be given where alternatives are available.

\section{References}

1 Report of the Occupational Pensions Board (1989) 'Protecting Pensions Safeguarding Benefits in a Changing Environment', see Cm573 HMS()

2 Syntegra Ltd "Syntegra Ltd Flexible Pension Plan (Kon653, 18th July, 2001)

3 Mrs E M O'Connor Re Darunn Clayton Ltd Small Self Admunstered Rettrement Benefits Scheme (Lo(0)87) 7th February, 2003

4 Pensions Schemes Act 1993, s. 151(2).

5 Royal Liver Friendly Society Penston Scheme, Ref. Mo0006, Complainant Mrs K. Holding, 29th August, 2003

$6 \quad R$ fon the application of Brtannic Asset Management Ltd) 1. Pensions Ombudsman [2002] 4 All ER 860

7 Contained in Section 146(4) Pension Schemes Act 1993

8 Legal \& General Assurance Soctety Ltd * CC.A Stationery Ltd [2000] 2 All ER 577. 